\title{
VERIFICATION OF SITUATIONAL LEADERSHIP TOOLS FOR WORKERS IN A FOUNDRY
}

\author{
${ }^{1}$ Andrea SAMOLEJOVÁ, ${ }^{1}$ Martin LAMPA \\ ${ }^{1}$ VSB - Technical University of Ostrava, Ostrava, Czech republic, EU, \\ andrea.samolejova@vsb.cz
}

https://doi.org/10.37904/metal.2020.3637

\begin{abstract}
Lack of qualified human resources has, for several years now, been the biggest constraint on the development of Czech industry, particularly in manufacturing facilities where working conditions are difficult. This category includes foundries. Therefore, these production facilities began addressing this problem through more intensive adaptation and in-house training of unskilled job seekers. The article presents the results of verifying the implementation of situational leadership tools in practice at a foundry and their impact on the development of employee work independence for a period of 4 months.
\end{abstract}

Keywords: Situational leadership, employee adaptation, work performance

\section{INTRODUCTION}

Employees are a key production factor of companies; however, their price, in the form of wages, is constantly growing due to long-term growing demand. In a profitable enterprise, the rising price of inputs to production must also be reflected in rising outputs, so that profit does not fall, and this rule also applies to inputs in the form of human resources. This rule of successful business is ensured and verified through the process of managing employee work performance.

The performance management process itself is or should be largely the responsibility of the direct superiors of the employees whose performance is managed. These begin to systematically manage the performance of subordinates from the moment of the employee's hiring. Due to the fact that there is a long-term shortage of qualified workers on the market, the importance of all training activities of companies is growing, especially introductory training - adaptation to a new job and environment. Managers need to adapt their leadership techniques to the employee's level of adaptation to the new position, more than ever before, so the authors decided to test the situational leadership tools of Hersey and Blanchard, whose basic variable "maturity" strongly resembles the extent to which the employee is adapted to the new position. Therefore, they monitored the development of maturity of new employees at a selected foundry for 4 months and, based on several maturity assessments, their managers evaluated the extent to which management style recommendations, based on the maturity of originally unskilled employees, enabled them to achieve full performance corresponding to that of a qualified, already experienced employee.

\section{THEORETICAL BACKGROUND}

Work performance can be defined as the result of work activity over a period of time under certain conditions [1]. The performance itself, i.e., the achievement of a certain level of fulfilment of the assigned task is influenced by many factors, but the leadership style of managers plays a major role [2], because work performance is not only the output of human activity, but also the way it is achieved [3]. Employee performance management means a clear definition of the employee's tasks and goals as well as creating conditions in which to perform work tasks as expected by the manager. 
In general, human resource management agents are divided into three groups: senior management/owner, personnel department, and line managers. Performance management mostly falls under the competence of line managers, because they are in closer contact with their subordinates than the personnel department or senior management. They can better influence the interconnection of their objectives and business goals [4]. Line managers share responsibility for the work performance of their subordinates, partly because their job is to create conditions for employees that allow them to work to the best of their abilities [5]. The systematic communication of managers with their subordinates allows prevention of many problems and leads to a reduction in the occurrence and recurrence of errors [5].

Current work performance management includes planning not only actual work performance, but also planning the employee's personal training and development (hereinafter only development) [6]. Once the specific performance and personal development have taken place, the phase of reviewing the actual performance and development achieved by the employee follows, along with the potential adoption of further measures [7]. Thus, in addition to the evaluation of performance, the basic pillars of work performance also include the training, development, and motivation of employees. All these areas already fall mainly within the competencies of line managers.

The employee's immediate supervisor, who manages and improves the employee's work performance, performs essential functions in the process of improving work performance, which should be part of the work performance management process [4]. First, the supervisor finds and defines the causes of gaps in work performance and areas in which the worker has room to improve. He or she then chooses the best measures, to eliminate the root causes of performance gaps, and contributes to their best implementation. After the monitoring period elapses, the supervisor then evaluates the impacts of the adopted measures and subsequent changes, so that the company's management can be informed on the success of the implemented measures.

\section{SITUATIONAL LEADERSHIP TOOLS}

All management and performance improvement roles require [5] leadership skills and the ability to identify and make use of an individual's untapped capacity. A key tool for managers, in performance management, is the constant motivation of employees and the development of the skills and knowledge of capable employees, as the company's best investment. The success of motivation depends on the level of knowledge of the individual needs of employees.

One of the most common areas of training engaged in abroad by line managers is so-called situational leadership, as described by authors Hersey and Blanchard. Situational leadership means engaging with subordinates through various leadership styles that are adapted to the current situation. This leadership style chooses between four approaches (see below). In this approach, maturity expresses readiness to perform a certain work task [8]. Maturity can therefore be viewed in two ways, as work-related (job) maturity or psychological maturity. Job maturity reflects the skills and technical knowledge needed to complete a task. Psychological maturity expresses the readiness to take responsibility for completing a task. To choose the appropriate leadership style, the manager must follow a sequence of three steps when managing work performance [9]:

1) Define a specific task required of the worker in the context of the worker's position

2) Determine the employee's readiness to perform the given task

3) Choose the appropriate leadership style

The authors of the method recommend four applied types of leadership styles, based on the maturity of the subordinate.

These are combinations of various levels of support-relationship and directive behaviour [8]: 
- $\quad$ The instructive-to-directive style most often corresponds to the level of development of an employee who has no experience with the given task. The manager chooses a strongly task-oriented approach, where not much space remains for the personal support of the employee.

- The coaching and supportive style will be used by the manager with a subordinate who already demonstrates a higher level of competence, is more actively engaged, but still does not have sufficient skills to work independently. The leader still instructs him, but he devotes the same amount of time to his psychological support and development.

- A participatory and supportive style is suitable for an employee who is highly competent and already independently active, but still needs advice and support, mostly for lack of self-confidence. The manager spends more time providing personal rather than work support.

- $\quad$ The delegating style is used by the manager with a subordinate who is highly competent and active in performing tasks and does not need personal support.

Individual leadership styles and their prerequisites are shown in Figure $\mathbf{1}$ below.

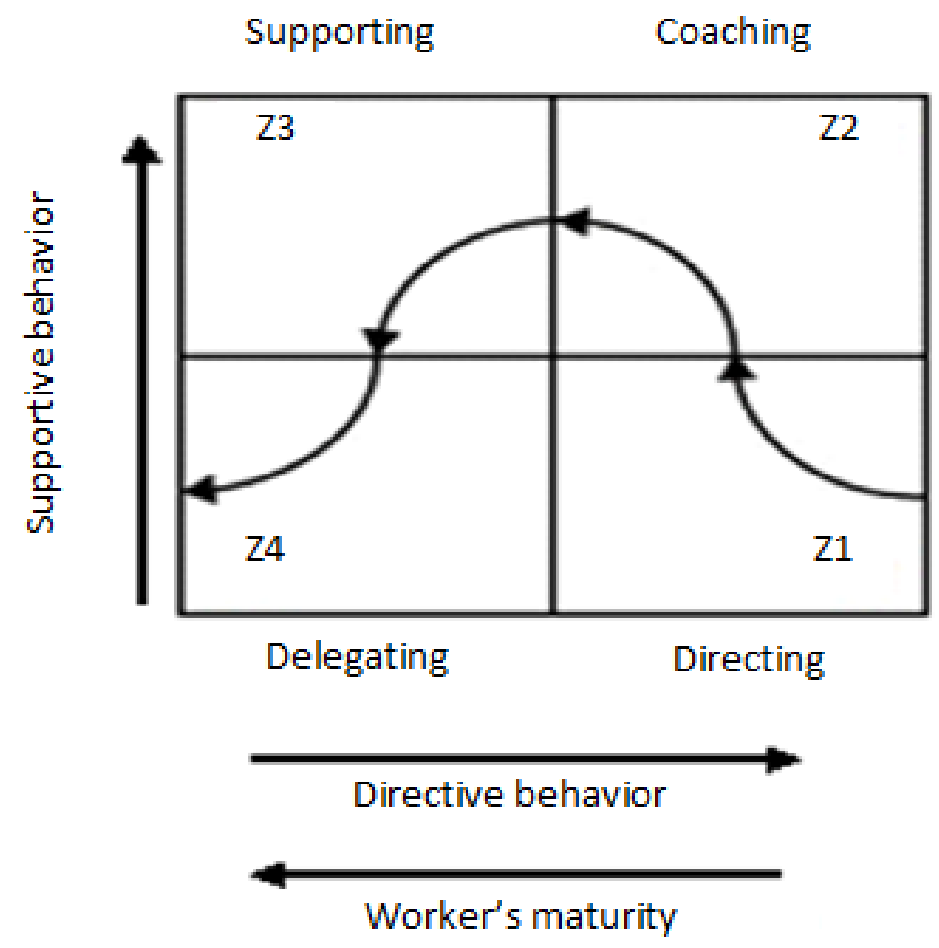

Figure 1 Styles of situational leadership according to Hersey and Blanchard [8]

This method is suitable where there is more frequent fluctuation and the manager must choose between different approaches to subordinates, because of their different maturity levels at work. Therefore, it is also suitable for foundries, which need to stabilize the staff, as older employees gradually retire.

\section{COMPANY ANALYSIS}

Among other things, the personnel analysis of the company showed that, due to the lack of qualified labour, it is forced to train and educate its employees at its own expense and this happens in the course of full work engagement of a newly hired, but often professionally unprepared, employee. Until now, they have taken an active but unsystematic approach to the training of new employees, with each manager and team choosing different tools. The authors therefore suggested managing the performance of these employees according to their level of maturity (in the sense of independence). The development of the employee's independence rested mainly on an appropriate style of leadership and the use of professional training methods, such as 
demonstrations and assistance, but also methods to support the employee's mental maturity, such as more frequent consultation and feedback than provided to experienced workers.

In the context of the work performance management system, the authors proposed introducing a clear register of planned and completed training activities for all employees, interconnected with the data from a new, interactive form for ascertaining a worker's job maturity level.

An overview of the planned and completed training activities also provides the employee with information on the achieved level of qualification, professionalism, and potentially regarding certifications and other skills earned. At the same time, the employee has available his or her own development activities plan for the next evaluation period, which is based on the process of evaluating and improving work performance and development.

The form with an interactive questionnaire responds to the situation of most smaller metallurgical companies, which must train new employees themselves, because the candidates do not have the necessary qualifications. These employees require greater attention from the manager than workers who are qualified, experienced, and can work independently. The form, supplemented by a detailed comment from the manager, served as a kind of instruction on how to behave in the individual phases of development of their subordinates, depending on how many points they received. The questionnaire and the whole procedure are based on a management technique that comprises the most popular training for line managers around the world.

The content of this approach was created based on the following prerequisites, which were successfully verified at the company:

I. There is a wide range of experience and expertise among workers within industrial enterprises (including metallurgical plants);

II. The most effective educational form of increasing the expertise and skills of less experienced workers is that experienced colleagues, so-called mentors, demonstrate and explain the scope of work to them;

III. Achieving higher work and psychological maturity must be motivated by external incentives from the employer, such as a graded task wage;

IV. The procedure must be simple and time-saving.

The questionnaire includes ten questions, of which the first five are used to determine the work maturity and the other five to define the psychological maturity of the worker. (The questionnaire is created based on the LEAD technique (Leadership Effectiveness \& Adaptability Description). LEAD is a standardized survey technique. The questions were taken from another survey for determining worker maturity in the Czech Republic, which was based on the LEAD-self technique [10] According to the results of the questionnaire (values from 0 - immature to 8-completely matured, independent worker whom leader can delegate work to), the manager should prefer one of the four possible management styles to achieve further employee development. The level of maturity was also considered in the employee's basic salary, to motivate them in their own education and development in accordance with the approach of their superior. The line managers of selected company workplaces, along with the production director, were initially trained by the authors of the article in this style of management, and the authors also provided them with instant support throughout the verification of the functionality of the approach at the company.

\section{RESULTS}

After the introduction of the questionnaire, the authors conducted an initial survey in cooperation with line managers, to determine the maturity of employees, so as to choose the right leadership style. These were then chosen by each line manager and applied to selected employees of their department. The same survey was repeated every month, for a total of four times. The questionnaire was always filled in by the heads of individual work departments for their subordinates and also by the head of production for all workers. A total of 9 foundry unskilled workers recruited in the last 3 months were monitored and evaluated in groups of 3 
(group 1 - hired more than 60 and less than 90 days before first evaluation start, group 2 - workers hired from 30 to 60 days before evaluation start and group 3 hired less than 30 days before evaluation start) The results are shown in Table 1. (Results are rounded to one decimal place)

Table 1 Average level of working maturity of selected foundry workers

\begin{tabular}{|c|c|c|c|c|c|c|c|c|}
\hline $\begin{array}{c}\text { Maturity evaluation } \\
\text { (every month) }\end{array}$ & $\mathrm{M} 1$ & $\mathrm{M} 2$ & $\Delta \%$ & $\mathrm{M} 3$ & $\Delta \%$ & $\mathrm{M} 4$ & $\Delta \%$ & $\Delta \mathrm{M} 1 \mathrm{M} 4 \%$ \\
\hline Group 1 & 5.1 & 5.7 & 11.8 & 6.6 & 15.8 & 7.8 & 18.2 & 52.9 \\
\hline Group 2 & 3.9 & 4.8 & 23.1 & 6.0 & 25.0 & 7.3 & 21.7 & 87.2 \\
\hline Group 3 & 3.4 & 4.1 & 20.6 & 5.5 & 34.1 & 7.0 & 30.0 & 118.8 \\
\hline Total average maturity grow & & & 18.5 & & 22.4 & & 23.3 & 86.3 \\
\hline
\end{tabular}

It is clear from the results that the average maturity of employees grew in 3 months only by $86.3 \%$ in average and it the least experienced group 3 even by almost $120 \%$ ! And these workers were led by already trained line managers for 3 months. All groups have reached maturity above point 7 when 8 means mature, independent, reliable worker to whom managers can delegate all tasks. And that is great success and confirmation of the importance of line managers' acquisition of situational leadership techniques.

In the period before the survey and the introduced questionnaire with systematic instructions for line managers on what leadership style to use for which employee, the development of employee maturity was not monitored with exactness. Therefore, in this phase of the survey, it is not possible to compare these outputs. Nevertheless, the director of the foundry sees the clear record of information on the maturity of evaluated employees, along with the unification of training styles in all workplaces, in a very positive light. Based on the positive results of testing, he decided to support this approach with motivational measures for both team leaders and mentors, who are more experienced team workers, who were and will continue to be involved in the training of less experienced (less mature work-wise and psychologically) colleagues in the team. He believes that, with stronger motivation, managers and mentors will be able to improve the work performance of their less-experienced charges faster.

\section{CONCLUSION}

The proportional positive relationship between the growth of work independence and the worker's experience and their work performance clearly amplifies the importance of training activities of companies. As the role of internal employee training increases in relation to external training, so too does the importance of involving line managers and more experienced employees in the company's training, as mentors, as part of the work performance management process.

According to the survey, the introduction and mainly training of the techniques and tools of situational leadership set out by authors Hersey and Blanchard proved to have a highly positive effect on the monitored company and its unexperienced workers' maturity. Line managers, with the help of experienced mentors, applied the recommended appropriate style of subordinate management at their workplace, to support the employee's performance in the relevant situation (i.e., according to his level of work maturity), as well as further development of the employee's maturity. Employees' base salaries were also graduated according to the achieved level of maturity, so that they too would be more motivated to pursue own further development. This also limits the subjectivity of managers' decisions on the base salary of subordinates. During the monitored period, the work performance and psychological maturity of selected employees increased by an average of almost $120 \%$, so they will continue in the established approach to leading and supporting new employees in the company. 
Employees represent the main potential source of increases in competitiveness of companies, and this resource can be activated only by constantly looking for opportunities to increase labour productivity, including via improving the work performance of employees through situational leadership tools.

\section{ACKNOWLEDGEMENTS}

The work was supported by the specific university research of Ministry of Education, Youth and Sports of the Czech Republic No. SP2020/61.

\section{REFERENCES}

[1] PAUKNEROVÁ, D. a kol. Psychologie pro ekonomy a manažery. 2. vyd., Praha: Grada Publishing, 2006.

[2] SMITHER, J. W., LONDON, M. Performance management: Putting research into action. John Wiley \& Sons, 2009.

[3] TURECKIOVÁ, M. Řizení a rozvoj lidí ve firmách. Praha: Grada Publishing, 2004.

[4] ARMSTRONG, M. Řizení lidských zdrojü: Nejnovější trendy a postupy. Grada Publishing, Praha, 2007.

[5] KOUBEK, J. Řizení pracovního výkonu. Praha: Management Press, 2004.

[6] SUCHÁČEK, J. Globalization and Glocalization. In the Scale of Globalization. Think Globally, Act Locally, Change Individually in the 21st Century. Ostrava: University of Ostrava, 2011.

[7] PULAKOS, E. D. Performance Management: A New Approach for Driving Business Results. John Wiley \& Sons, 2009.

[8] BĚLOHLÁVEK, F. Jak vést rozhovory s podřizenými pracovníky. Praha: Grada Publishing, 2009.

[9] GRIFFIN, R., MOORHEAD, G. Organizational behaviour: Managing people and organizations. Mason: Cengage Learning, 2010.

[10] WOTAVOVÁ, P. Teorie situačního vedení a její aplikace v oblasti oční optiky v České republice. Rigorózní práce. Karlova univerzita, 2012. 